chemical action which takes place when calcium carbide comes in contact with any mucous surface $I$ suggest that some protection for workers with it is imperative. I am, Sirs, yours faithfully

Dublin, Feb. 5th, 1902 J. C. MoWalter, M.A., D.P.H.

\section{THE MIDWIVES ACT.}

To the Editors of THE LANCET.

SIRS,-The passing of the Midwives Act of 1902 devolves a grave responsibility on the nation in order that, as the untrained midwife vanishes, the poor who either cannot, or will not, be attended by medical men may not be left without necessary assistance. A clergyman writes to me, "We have no maternity charity or help of any sort towards doctor or nurse ;...... it is sad to see the suffering from neglect and ignorance and feel utterly at the mercy of these untrained women. How the Act will affect us I cannot guess if it stops the present dangerous system and gives us nothing in its place. I am not sure that it will be an advantage. I am sure our poor women won't consider it so. They can't afford to engage a trained monthly nurse, especially from a distance, or to send for a doctor."

Now it is to help these remote scattered parishes, as well also as the crowded provincial towns where these untrained women are so numerous and prosperous that $I$ am anxious to gain the sympathy of those able to help. First of all, I would enlist the coopperation of the local medical man who feels that the village midwife working under proper supervision would be a help rather than a hindrance to his workof the busy and often overworked family practitioner who recognises the fact that such women will relieve the pressure by taking those cases that use up his most valuable time and pay so little, if at all, and whom he may trust to send for him in good time when surgical skill is required. Then I would, where nursing associations exist or could be started, have one or two midwives attached and thus make use of existing organisations where possible. 1 have done this in my own case; the woman prepays an extra fee of from $5 s$. to $10 \mathrm{~s}$., which is returned to her if the medical man is not required. If he is sent for the association guarantees the payment

In very sparsely populated districts one or two might join together to provide a midwife, and the midwife might be encouraged to combine with her work some occupation not detrimental to her calling. In towns the work would become quickly self-paying, and I feel that a very moderate outlay would start a sound, substantial work. I cordially invite those interested, and especially medical men who approve of this scheme, to communicate with me, and I wonld ask others to help me with funds to make a good beginning.

I am, Sirs, yours faithfully,

JOSEPHINE JOHNSTONE.

Bignor Park, Pulborough, Feb. 7th, 1903.

\section{THE SURGICAL TREATMENT OF RHEUMATIC FEVER.}

To the Editors of THE LANCET.

SiRS,-From a long experience in South China, I can fully confirm the statements made by Dr. A. Haig in his letter under the above heading in THE LANCET of Feb. 7th, p. 398. Arthritic pains of all kinds are quickly relieved by the salicylates during the cool season, but much harm may follow if given when the thermometer stands above $80^{\circ} \mathrm{F}$.

I am, Sirs, yours faithfully, EDWARD HORDER, F.R.C.S. Edin.

Limpsfield, Feb. 9th, 1903.

\section{"TIS FORTY YEARS SINCE."}

\section{To the Editor's of THE LANCET.}

SiRS,-Having had occasion to refer to the lists of the London hospital staffs of 40 years ago as given in the Students' Number of THE LANCET of Sept. 20th, 1862, I think that it may interest your readers if I give a brief summary as to the survivorship of these gentlemen. Of course all who held office in 1862 have retired from active hospital work, as life appointments have long ceased to exist, and I shall only mention those still living.

At St. Bartholomew's Mr. Luther Holden, then assistant surgeon, is the sole survivor of the hospital staff, and Sir Thomas Smith, K.C.V.O., then demonstrator, of the teaching staff. At Charing Cross Mr. R. Barwell, then assistant surgeon, alone survives. At St. George's Sir Henry Pitman and Dr. J. W. Ogle, who were physician and assistant physician, Mr. Holmes, assistant surgeon, and Dr. W. Ogle, lecturer on physiology, survive. At Guy's Sir S. Wilks and Dr. F. W. Pavy, assistant physicians, Mr. J. Birkett, surgeon, and Mr. T. Bryant, assistant surgeon, remain. At King's College Dr. L. S. Beale, physician, Dr. A. B. Duffin, Dr. E. Thompson, and Dr. E. Liveing, assistant physicians, and Mr. Spencer Watson, assistant surgeon, remain. At the London Dr. R. Barnes, obstetric physician, and Mr. J. Hutchinson, Mr. J. Couper, and Mr. L. S. Little, assistant surgeons, survive. At St. Mary's Sir E. H. Sieveking, physician, with Sir W. H. Broadbent (physiology), and Mr. A. H. Norton, demonstrator, are the survivors. At the Middlesex Mr. Mitchell Henry and Mr. T. W. Nunn, assistant surgeons, and Dr. R. Liveing, demonstrator, survive. At the Royal Free Mr. Thomas $H$ Wakley and Mr. F. J. Gant, surgeons, and Mr. Hasler Harris, dental surgeon, remain. At St. Thomas's Dr. E. Clapton, assistant physician, Dr. H. Gervis, assistant accoucheur, Sir John Simon, K.C.B., surgeon, and Mr. Sydney Jones, assistant surgeon, survive. At University Sir Alfred B. Garrod, physician, and Sir H. Thompson, assistant surgeon, with Professor Williamson (chemistry), and Professor Oliver (botany) remain. At Westminster Dr. P. W. Latham, assistant physician, and Mr. H. Power and Mr. C. Heath, assistant surgeons, and Dr. Dupré (chemistry) survive.

I am, Sirs, yours obediently,

Historicus.

\section{NOTES FROM INDIA \\ (From oUR SPecial CORRespondent.)}

The Plague Epidemic.

THE mortality from plague throughout India is advancing by leaps and bounds. This week the total has risen to 19,224. The details published are: Bombay Presidency, 8962 deaths; the Punjab, 2442 ; the United Provinces, 2291 ; Bengal, 2124; the Central Provinces, 605; the Madras Presidency, 683 ; the Mysore State, 806 ; Bombay City, 443; and Calcutta, 37. In Poona the disease is raging very virulently; rearly 100 deaths are occurring daily, the normal death-rate of the city being 12 . In Calcutta a fresh outbreak has started and the figures are running up rapidly. This year the general development of plague is more widespread and involves a larger population than at any previous period. The Government has been compelled to abandon the system of inspection for plague on the railways in the United Provinces as hopeless. This inspection is credited with having postponed the invasion of certain areas, but when the disease has once attacked a province precautions on the railways are of no further avail.

Jan. 24th.

Presentations to Medical Practitioners. - At an "At Home" held at the Bath Saloon, Truro, on Feb. 5th, the Mayor of Truro, on behalf of the subscribers, presented Mr. Frederick Harold Carlyon, M. D., C.M. Edin., with an illuminated address and a cheque for $£ 55$ as a mark of respect and esteem on the occasion of his leaving for Johannesburg. The Mayoress presented Mrs. Carlyon with a diamond and sapphire bracelet.-Mr. Michael Halpenny, L.R.C.P., L.R.C.S. Edin., L.F.P.S. Glasg., has recently been presented with a gold semi-hunter keyless watch and a purse containing a sum of money by the inhabitants of Gilfach Goch. Mr. Halpenny recently left Gilfach Goch to practise in Ireland - At De Keyser's Royal Hotel, Thames-embankment, London, E.C., on Feb. 4tb, Mr. Theophilus Hoskin, J.P., L. R C.P. Lond., M.R.C.S. Eng., was presented by the Master of the Worshipful Company of Makers of Flaying Cards with a silver salver bearing the following inscription :"Presented to Dr. Theophilus Hoskin, J.P., by his colleagues on the Court of Assistants of the Worshipful Company of Makers of Playing Cards, in commemoration of his services to the Company as Master, 1901-1902." 